\title{
Structural and magnetic properties ofNanocrystalline Nickel ferriteprepared byCitrate Sol-geland Solid- state reaction techniques
}

\author{
R.M.Hamdy ${ }^{1}$, M.B.S.Osman ${ }^{1}$, Y.M.abbas ${ }^{2}$, M.A.Ahmed ${ }^{3}$ \\ ${ }^{1}$ Physics Department, Faculty of Women for Arts, Science and Education, Ain Shams \\ University, Cairo, Egypt \\ ${ }^{2}$ Physics Department, Faculty of Science, Suez Canal University, Ismailia, Egypt \\ ${ }^{3}$ Physics Department, Faculty of Science, Cairo University, Giza, Egypt
}

\begin{abstract}
The structure and magnetic properties ofnanocrystalline nickel ferrite powder $\mathrm{NiFe}_{2} \mathrm{O}_{4}$ has been investigated using two different preparation methods, including the ceramic technique and citrate method. The synthesized powders were characterized using X-ray Diffraction (XRD) for crystallite size, X-ray density and lattice parameter calculation. The results indicated that the citrate method gives the lowest value for the lattice parameter and crystallite size $(60.6 \mathrm{~nm})$ in citrate method and $(73.8 \mathrm{~nm})$ in ceramic method. Distribution of cations among the two interstitial sites (tetrahedral and octahedral sites) has been estimated by analyzing the powder Xray diffraction patterns by employing Rietveld refinement technique, and the results reveal the existence of samples asinverse spinelwith cubic structure and Fd-3m space group.The morphological investigations using Field Emission Scanning Electron micrograph (FE-SEM) and

High Resolution Transmission Electron Microscopy (HR-TEM).The elemental analysis of samples usingEnergy Dispersive X-ray Analysis (EDAX) .Magnetic measurements of the samples at room temperature were carried out by means of vibrating sample magnetometer (VSM).
\end{abstract}

Key words: Nickel ferrite, Rietveld, Cation distribution

\section{Introduction}

The ferrite of greatest technical importance is derived crystallographically from three natural compounds: the spinel, the garnet, and the magentoplumbite.Spinel is an important class of mixed-metal oxides, which has the structure of the natural spinel $\mathrm{MgAl}_{2} \mathrm{O}_{4}$ and the general chemical composition of $\mathrm{AB}_{2} \mathrm{O}_{4}, \mathrm{~A}$ and $\mathrm{B}$ can be divalent, trivalent cations. The physical properties of the spinel ferrites are controlled by the choice of the cations and their distribution between tetrahedral and octahedral sites of the structure. Nickel ferrite is one of the multifaceted and technologically important soft ferrite materials because of its typical ferrimagnetic properties, lower eddy current losses, low conductivity and high electrochemical stability[1-2]. Nickel ferrite is veryattractive in recent research works because of its higherelectromagnetic performance,

Corresponding author: reem90abbas@gmail.com 
excellent chemical stability,mechanical hardness, high coercivity, and moderate saturationmagnetization [3].

Nickel ferrite $\left(\mathrm{NiFe}_{2} \mathrm{O}_{4}\right)$ belongsto the inverse spinel. In this structure the 32 divalent oxygen ions formed a closed packed FCC arrangement with 64 tetrahedral interstitial A-sites and 32 octahedral B-sites. Out of these, the divalent $\left(\mathrm{Ni}^{2+}\right)$ and trivalent $\left(\mathrm{Fe}^{3+}\right)$ cationsoccupy one-eighth of A-sites and half of the B-sites [4]. Among these nanomaterials, the magnetic nanomaterials are more interesting owing to their medical, electronic and recording applications. These applications depend on the size, shape, purity and magnetic stability of these materials [5] such as wave absorber, magnetic core memory devices and carriers of drug inside the body [6] this paper compares between the synthesis of $\mathrm{NiFe}_{2} \mathrm{O}_{4}$ nanoparticles which prepared by ceramic technique and citrate route, The results for the structural and elemental analysis by XRD, EDAX, FE-SEM and HR-TEM and magnetic properties characterized by VSM are discussed.

\section{Experimental}

\subsection{Synthesis techniques}

\section{(1) Ceramic precursor: sample $\mathrm{S1}$}

The starting materials were stoichiometric quantities of analytical reagent grade powders of $\mathrm{Fe}_{2} \mathrm{O}_{3}$ and $\mathrm{NiO}$; all $99.9 \%$ pure, supplied by LobaChemie used for the polycrystalline samples of Nickel ferrite. They were first the stoichiometric mixtures of all the ingredients were thoroughly mixed in wet medium (acetone) and then grinded for 5hours in an agate mortar to obtain a very fine powder of good homogeneity. The mixture was then presented at $700^{\circ} \mathrm{C}$ for $6 \mathrm{~h}$ at a heating / cooling rate 5 degrees/min in high purity crucibles. The presintering process to ensure that all the carbon is liberated from the mixture in the form of $\mathrm{CO}_{2}$. The presintered mixture was again well grinded for $15 \mathrm{~min}$ then pressing by the hydraulic press to pellets and resulting were finally sintered at $1100^{\circ} \mathrm{C}$ for 6 h.we denote this sample as $\mathrm{S} 1$.

\section{(2) Citrate precursor: sample $\mathbf{S 2}$}

The starting materials were analytical reagent grade powders of $\mathrm{Fe}\left(\mathrm{NO}_{3}\right)_{3} \cdot 9 \mathrm{H}_{2} \mathrm{O}$ and $\mathrm{Ni}\left(\mathrm{NO}_{3}\right)_{2} .6 \mathrm{H}_{2} \mathrm{O}$; all $99.9 \%$ pure. The molar ratio of metal nitrates to citric acid was taken as 1:1 molar ratio. The metal salts and citric acid dissolved in minimum amount of de-ionized water and PH was adjusted to 7 by using ammonia. Then the mixture was heated on the hot plate, the decomposition reaction would not stop before the whole citrate complex was consumed. The auto-ignition was completed within a minute, yielding the brown- colored ashes termed as a precursor. The as-prepared powder of the sample was annealed at $900{ }^{\circ} \mathrm{C}$ for $4 \mathrm{~h}$ with rate 5 degree/min.we denote this sample as $\mathrm{S} 2$. The flow chart of the synthesis route of eachmethod is shown in fig. (1). 
(a)

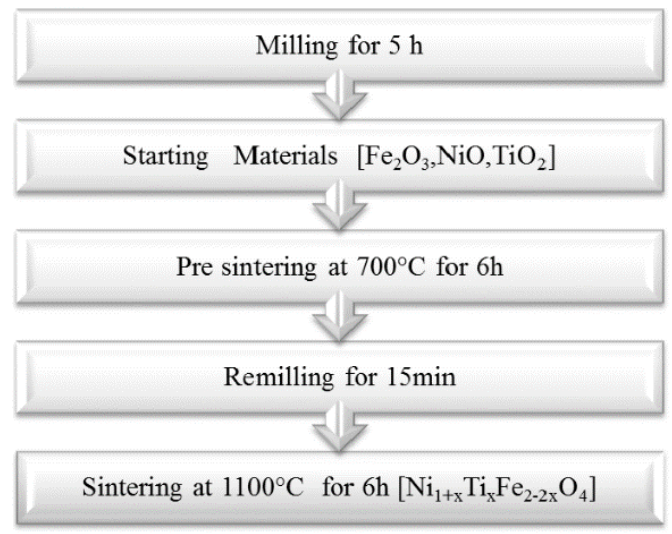

(b)

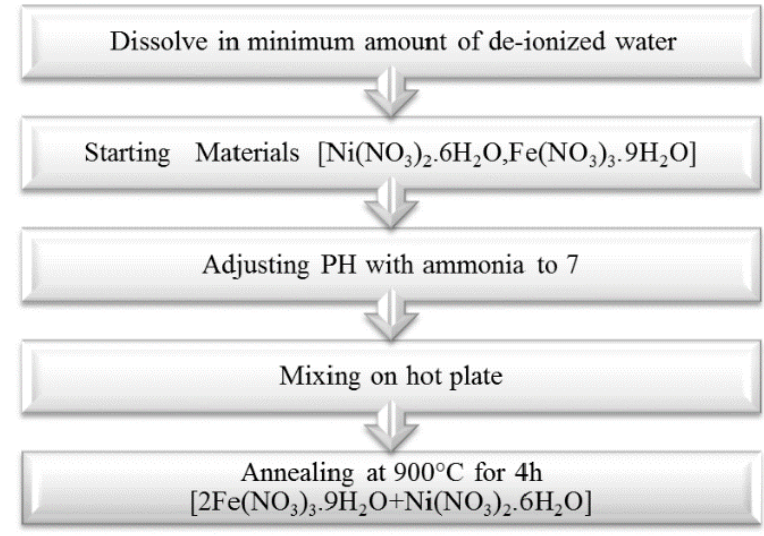

Fig.(1). flowchart for the synthesis of $\mathrm{NiFe}_{2} \mathrm{O}_{4}$ by (a) ceramic method (b) citrate method.

\subsection{Characterizationoftheassynthesizedmaterials}

The crystalline phase of all the samples was identified at room temperature using PhilipsX-ray Diffraction Instrument with X'pert MPD Diffractometer, with $\mathrm{CuK}_{\alpha}$ radiation $\left(\lambda=1.54060{ }^{\circ} \mathrm{A}\right)$. All the X-ray diffraction (XRD) patterns were analyzed with the help of FullProfprogramme by employing Rietveld refinement technique. The XRD patternsfor all the samples could be refined using the Fd-3m space group [7]. The Rietveld method is awell-established technique for extracting structural details from powder diffraction data. The method employs a least-squares procedure to compare Bragg intensities and those calculated from a possible structural model. In the first step of refinement, the global parameters, such as background and scale factors, were refined. In the next step, the structural parameters such as lattice parameters, profile shape and width parameters, preferred orientation, asymmetry, isothermal parameters, atomic coordinates, and site occupancieswere refined in sequence. The fitting quality of the experimental data is assessed by computing the parameters such as the 'goodness of fit' $\chi 2$ and the $\mathrm{R}$ factors ( $\mathrm{R}$

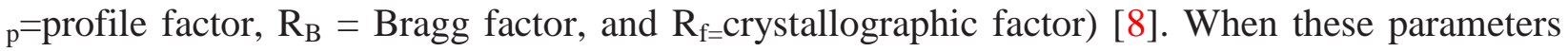
reached their minimum value, the best fit to the experimental diffraction data is achieved. We have calculated the crystallite size by The Scherrer's formula [9] is defined as

\section{$D=k \lambda / \beta \operatorname{Cos} \theta$}

where Scherrerconstant $\mathrm{k}$ depends upon the shape of the crystal (which is equivalent to 0.9, assuming the spherical grain), $\beta$ is the full width at half maximum of the intensity (in radian) vs. $2 \theta$ profile, $\lambda$ is the wavelength of the $\mathrm{CuK}_{\alpha}$ radiation (equal to $0.1540 \mathrm{~nm}$ ), $\theta$ is the Bragg's diffraction angle, and $D$ is the crystallite size. In Scherrer's formula, the average crystallite size has been calculated using Gaussian fit, fitted to the peaks in XRD pattern. D has been taken average for all the peaks.

The X-ray density was calculated using the molecular weight and the lattice constant. The XRDdensity was calculated by formula [10]

$$
\rho_{X R D}=8 \mathrm{M} / \mathrm{Na}^{3}
$$


Where $\mathrm{M}$ is molecular weight of the sample and $\mathrm{N}$ is the Avogadro number (equal to $6.022140857 \times 10^{23}$ )and ' $a$ ' is the lattice parameter.

The morphology, structure and elemental composition of $\mathrm{NiFe}_{2} \mathrm{O}_{4}$ were characterized by Fieldemission Scanning electron microscopy (FE-SEM) (QUANTA FEG 250) and Energy dispersive $\mathrm{X}$-ray analysis (EDAX) were performed to determine the Chemical composition of the elements present from the surface to the interior of the solids and to confirm the homogeneity of the as prepared samples.High-resolution transmission electron microscopy(HR-TEM) analysis was performed in a JEOL (JEM-2100); HR-TEM micrographs were used to characterize the particle size, shape, grain size and to confirm the lattice parameter variation across the interfaces using selected area electron diffraction (SAED) pattern.

\subsection{Magnetic study}

The magnetic properties of the investigated solids were measured at room temperature using a vibrating sample magnetometer (VSM; Lake Shore, Model-7410). From the obtained hysteresis loops, the saturation magnetization $\left(\mathrm{M}_{\mathrm{s}}\right)$, remanence magnetization $\left(\mathrm{M}_{\mathrm{r}}\right)$, coercivity $\left(\mathrm{H}_{\mathrm{c}}\right)$ and Squareness ratio were determined.

\section{Results and discussion}

\subsection{XRD analysis}

The X-ray diffraction pattern study for the nickel ferrite nanoparticles synthesized by ceramic and citrate precursor was done to identify the possible formation of single phase. The diffraction peaks for the synthesized nickel ferrite nanoparticles samples correspond to well indexed reflection planes (111), (2 2 0), (3 11 1), (2 2 2), (4 0 0 $)$, , (4 2 2 2), (5 11 1), (4 4 0) and (533) are shown in Fig.1, which thisplanes indicating the cubic spinel structure of nickel ferrite. No impurity peaks are observed in the XRD spectra of as synthesizedsamples. The average particle size of the nickel ferrite nanoparticles samples calculated from theScherrer's formula, the lattice parameter and The X-ray density is shown in Table 1.

Table 1 XRD parameters of $\mathrm{NiFe}_{2} \mathrm{O}_{4}$

\begin{tabular}{lcc}
\hline & $\begin{array}{c}\text { Sample } \mathrm{S1} \mathrm{NiFe}_{2} \mathrm{O}_{\mathbf{4}} \text { :ceramic } \\
\text { method }\end{array}$ & $\begin{array}{c}\text { Sample } \mathrm{S2} \mathrm{NiFe}_{2} \mathrm{O}_{\mathbf{4}} \text { :citrate } \\
\text { Method }\end{array}$ \\
\hline $\mathbf{D}(\mathbf{n m})$ & 73.8 & 60.6 \\
$\boldsymbol{\rho}_{\mathbf{X R D}}\left(\mathbf{g} / \mathbf{c m}^{\mathbf{3}}\right)$ & 5.20 & 5.37 \\
$\mathbf{a}\left({ }^{\circ} \mathbf{A}\right)$ & 8.337 & 8.335
\end{tabular}




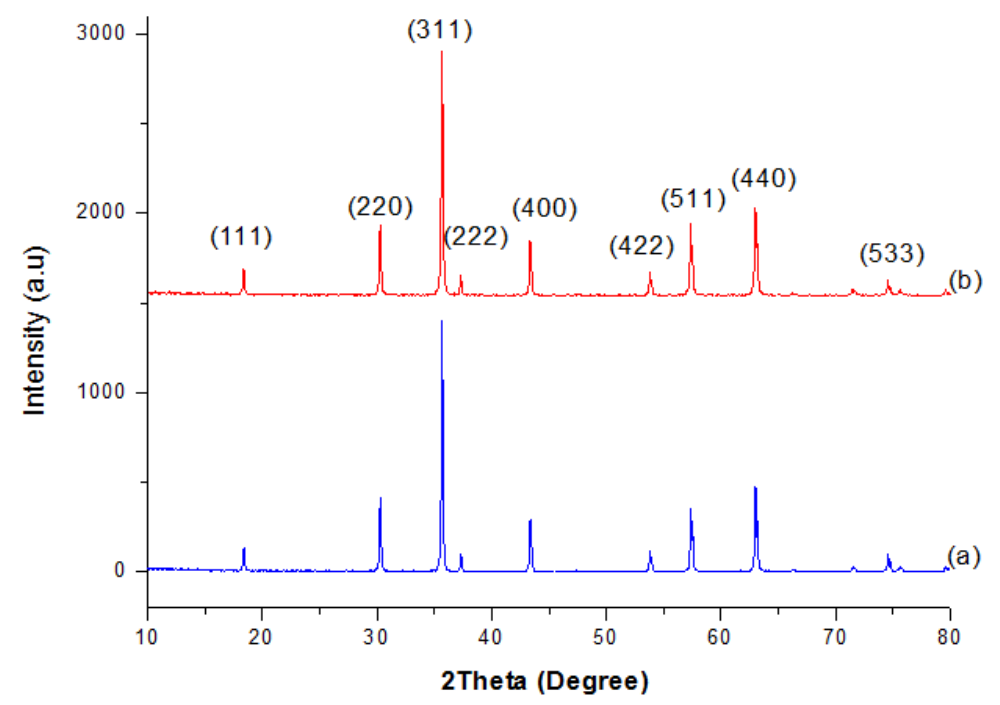

Fig.1 powder XRD patterns of $\mathrm{NiFe}_{2} \mathrm{O}_{4}$ nanoparticles prepared by

(a) Ceramic route (sample S1) (b) Citrate route (sample S2)

The X-ray diffraction patterns along with Rietveld refined data have been shown in Fig.2a,b for the samples S1 (prepared by the ceramic precursor method) and S2 (prepared by the citrate precursor method), respectively. The allowed Braggs positions for the Fd-3m space group are marked as verticallines. We have observed that all the experimentalpeaks are allowed Bragg $2 \theta$ positions for $\mathrm{Fd}-3 \mathrm{~m}$ space group.In the refinement,the oxygen positions $(\mathrm{x}=\mathrm{y}=\mathrm{z})$ have been taken as free parameters. However, all other atomic fractional positions have been taken as fixed. Other parameters such as lattice constants, isothermalParameters, occupancies, scale factors, and shape parameters have been taken as free parameters. The background has been corrected by pseudo-Voigt function. Typical fractional positions of the atoms for samples S1 and S2 are given in Table 2. The refined XRD patterns show that the samples are in single phase form. The various $\mathrm{R}$ factors are listed in Table 2. We have observed a lowvalue of $\chi^{2}$ (goodness of fit) which justifies the goodness ofrefinement. The refined lattice parameters and unit cell volumes forSamples S1 and S2 have been listed in Table 3.Bond lengths and bond angles were calculated using refined lattice parameters and fractional coordinates with the help of Diamond programme. Typical unit cell showing bond length between cations and anions forSamples S1and S2 has been depicted in fig 3a, b. The values of bond lengths and bond angles for samples S1 and S2 are listed in Table 4. 
(a)
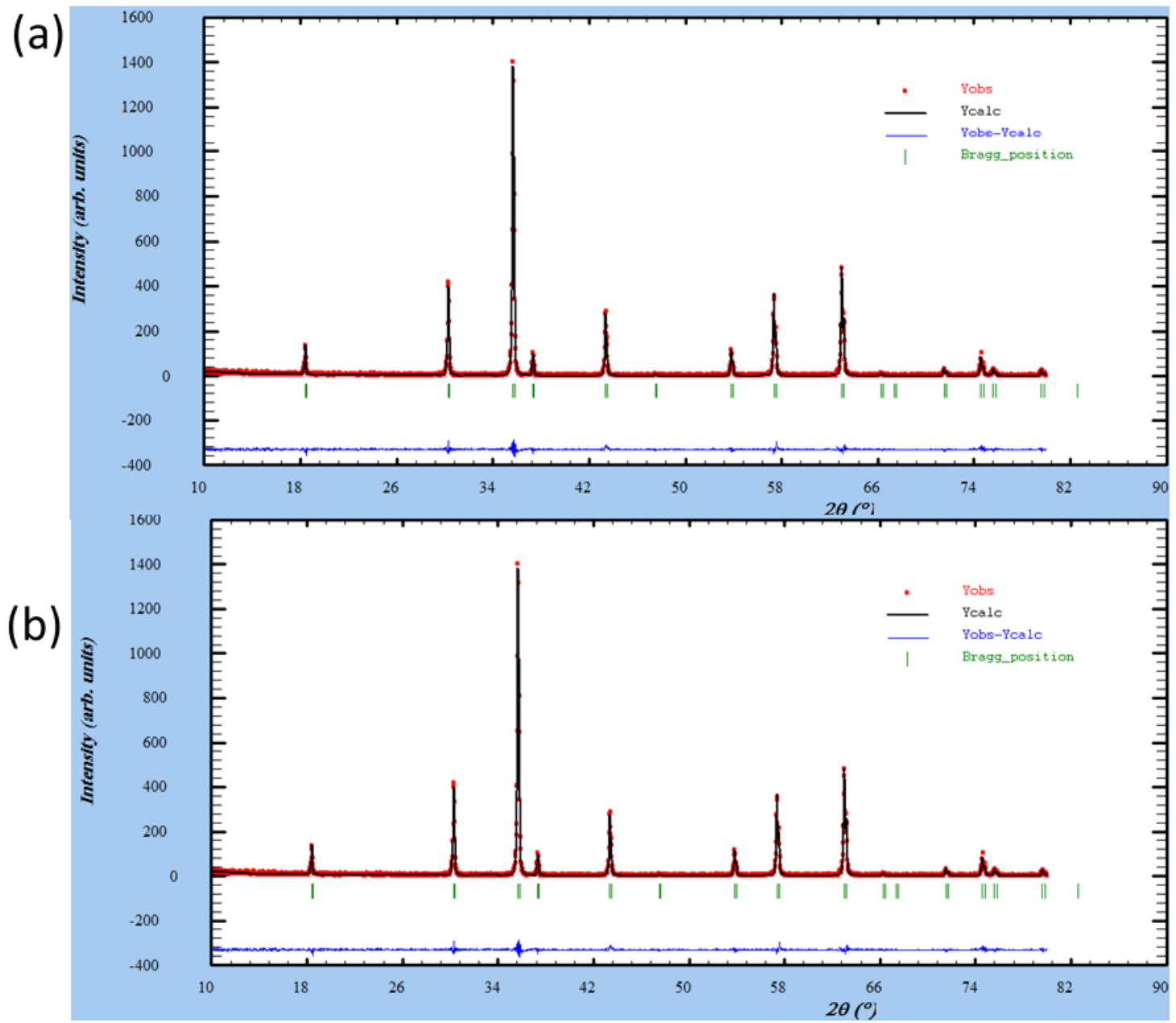

Fig.2 Rietveld refined XRD patterns for samples (a) $\mathrm{S} 1\left(\mathrm{NiFe}_{2} \mathrm{O}_{4}\right.$ :ceramic method) (b) $\mathrm{S} 2$ $\left(\mathrm{NiFe}_{2} \mathrm{O}_{4}\right.$ : citrate method)

We have observed that sample S1 has a larger crystallite size than sample S2. Although both samples were prepared under identical conditions, the crystallite size was not the same. The crystallite size is related to the relative

Inter dependence between the nucleation and growth steps, and it is strongly affected by the synthesis route. Thus, the citrate precursor method makes the formation of crystallites easier due to suitable growth of the crystals.

One can see that $\mathrm{Ni}$ ions are present on both tetrahedral and octahedral sites and Fe ions are present on both tetrahedral and octahedral, which reveals that the samples are in inverse spinel structure irrespective of the preparation method. 
Table 2Typical atomic coordinate $(x, y, z)$ of different atoms for samples S1 and S2

\begin{tabular}{ccccc}
\hline Method & Atoms & $\mathbf{x}$ & $\mathbf{y}$ & $\mathbf{z}$ \\
\hline Ceramic method & & & \\
& $\mathrm{Fe}$ & 0.12500 & 0.12500 & 0.12500 \\
$\mathrm{Ni} / \mathrm{Fe}$ & 0.50000 & 0.50000 & 0.50000 \\
$\mathrm{O}$ & & & 0.25450 \\
& 0.25450 & 0.25450 & \\
\hline & & & \\
Citrate method & $\mathrm{Fe}$ & 0.12500 & 0.12500 & 0.12500 \\
& $\mathrm{Ni} / \mathrm{Fe}$ & 0.50000 & 0.50000 & 0.50000 \\
$\mathrm{O}$ & & & 0.25522 \\
& & & & \\
\hline
\end{tabular}

Table 3Rietveld agreement factors, lattice constant, and unit cell volume of samples S1 and S2 at

\begin{tabular}{|c|c|c|}
\hline & $\begin{array}{c}\text { Sample } \mathrm{S1} \mathrm{NiFe}_{2} \mathrm{O}_{4} \text { :ceramic } \\
\text { method }\end{array}$ & $\begin{array}{c}\text { Sample S2 } \mathrm{NiFe}_{2} \mathrm{O}_{4} \text { :citrate } \\
\text { Method }\end{array}$ \\
\hline $\mathbf{R}_{\mathrm{p}}(\%)$ & 18.3 & 19.6 \\
\hline $\mathbf{R}_{\mathrm{B}}(\%)$ & 3.37 & 3.97 \\
\hline $\mathbf{R}_{\mathrm{f}}(\%)$ & 2.50 & 2.77 \\
\hline$\chi^{2}$ & 0.844 & 1.07 \\
\hline$a=b=c\left({ }^{\circ} A\right)$ & 8.3371 & 8.3359 \\
\hline $\mathrm{V}\left({ }^{\circ} \mathrm{A}\right)^{3}$ & 579.498 & 579.249 \\
\hline
\end{tabular}

$\mathrm{R}_{\mathrm{p}}$, profile factor; $\mathrm{R}_{\mathrm{B}}$, Bragg factor; $\mathrm{R}_{\mathrm{f}}$, crystallographic factor; $\chi^{2}$, goodness of fit factor; $\mathrm{a}$, lattice constant; $V$, unit cell volume. 


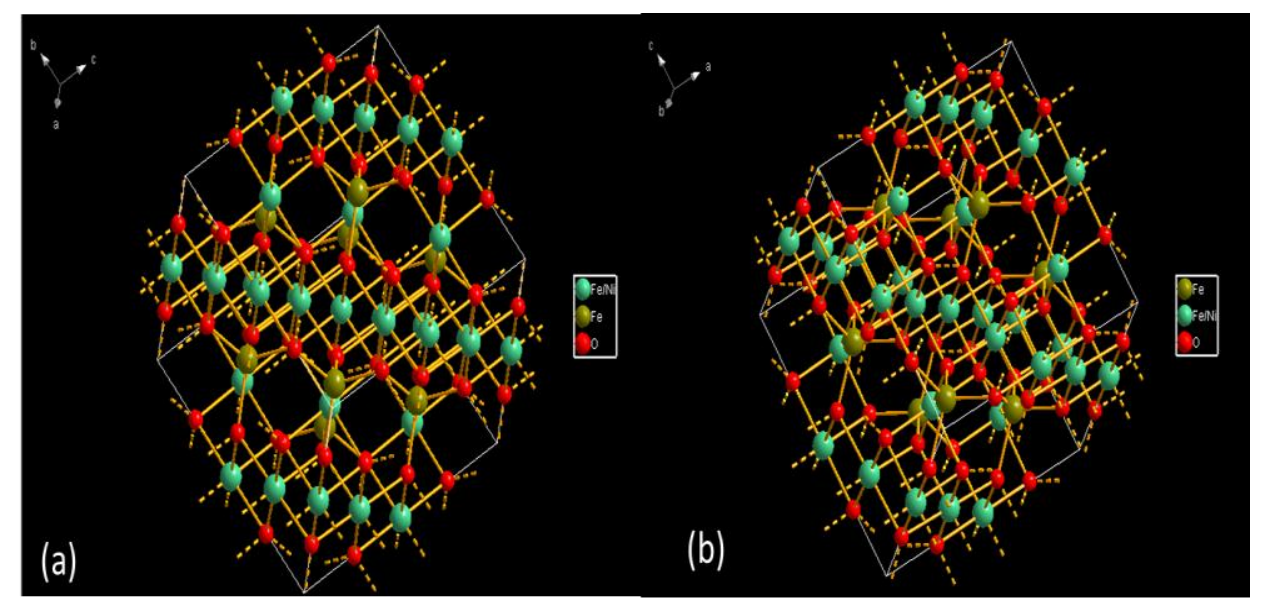

Fig.3 The crystal unit cell of $\mathrm{NiFe}_{2} \mathrm{O}_{4}$ (a) sample $\mathrm{S} 1$ (ceramic method) (b) sampleS2(citrate method)

Table 4Bond lengths and Bond angles between atoms ofSample $\mathrm{S1} \mathrm{NiFe}_{2} \mathrm{O}_{4}$ and $\mathrm{Sample} 2$ $\mathrm{NiFe}_{2} \mathrm{O}_{4}$

\begin{tabular}{|c|c|c|c|c|c|}
\hline \multicolumn{6}{|c|}{ Sample $\mathrm{S1} \mathrm{NiFe}_{2} \mathrm{O}_{4}$} \\
\hline Atom 1 & Atom 2 & $\mathrm{~d} 1,2\left[{ }^{\circ} \mathrm{A}\right]$ & Atom 3 & $\begin{array}{r}\text { d } 1,3 \\
\quad\left[{ }^{\circ} \mathrm{A}\right]\end{array}$ & $\begin{array}{r}\text { Angle } \\
2,1,3\end{array}$ \\
\hline \multirow{3}{*}{$\mathrm{Fe} \mid \mathrm{Ni}$} & $\mathrm{O}$ & 2.0475 & $\mathrm{O}$ & 2.0475 & 87.881 \\
\hline & $\mathrm{O}$ & 2.0475 & $\mathrm{O}$ & 2.0475 & 92.119 \\
\hline & $\mathrm{O}$ & 2.0475 & $\mathrm{O}$ & 2.0475 & 179.988 \\
\hline $\mathrm{Fe}$ & $\mathrm{O}$ & 1.87 & $\mathrm{O}$ & 1.87 & 109.471 \\
\hline \multirow[t]{2}{*}{$\mathrm{O}$} & $\mathrm{Fe}$ & 1.87 & $\mathrm{Fe} \mid \mathrm{Ni}$ & 2.0475 & 123.779 \\
\hline & $\mathrm{Fe} \mid \mathrm{Ni}$ & 2.0475 & $\mathrm{Fe} \mid \mathrm{Ni}$ & 2.0475 & 92.08 \\
\hline \multicolumn{6}{|c|}{ Sample $\mathrm{S} 2 \mathrm{NiFe}_{2} \mathrm{O}_{4}$} \\
\hline Atom 1 & Atom 2 & $\mathrm{~d} \mathrm{1,2}\left[{ }^{\circ} \mathrm{A}\right]$ & Atom 3 & $\begin{array}{r}\text { d 1,3 } \\
\left.\quad{ }^{\circ} \mathrm{A}\right]\end{array}$ & $\begin{array}{r}\text { Angle } \\
2,1,3\end{array}$ \\
\hline \multirow[t]{3}{*}{$\mathrm{Fe} \mid \mathrm{Ni}$} & $\mathrm{O}$ & 2.0414 & $\mathrm{O}$ & 2.0414 & 92.468 \\
\hline & $\mathrm{O}$ & 2.0414 & $\mathrm{O}$ & 2.0414 & 87.532 \\
\hline & O & 2.0414 & O & 2.0414 & 180 \\
\hline $\mathrm{Fe}$ & $\mathrm{O}$ & 1.8802 & $\mathrm{O}$ & 1.8802 & 109.471 \\
\hline \multirow[t]{2}{*}{$\mathrm{O}$} & $\mathrm{Fe}$ & 1.8802 & $\mathrm{Fe} \mid \mathrm{Ni}$ & 2.0414 & 123.537 \\
\hline & $\mathrm{Fe} \mid \mathrm{Ni}$ & 2.0414 & & 2.0414 & 92.416 \\
\hline
\end{tabular}




\subsection{Field-Emission Scanning Electron micrograph with EDAX analysis:}

The surface morphology characteristics of the synthesized nickel ferrite nanoparticles synthesized by ceramic and citrate method were investigated using (FE-SEM). Fig. 4a, cclearly shows the cubic shape of nickel ferrite nanoparticles and the morphology of the particles isvery similar. It also indicates the polyhedral shape and narrow size distribution of the particles. As the sample synthesized by citrate results in a very fine powder, so there is formation of soft agglomeration between particles of Nickel ferrite.

Fig. 4b, d shows the EDAX pattern for the elemental analysis of nickel ferrite nanoparticles. The elemental analysis confirms the homogeneous mixing of $\mathrm{Ni}, \mathrm{Fe}$ and $\mathrm{O}$ atoms. As there is noimpurity peaks observed in the EDAX spectrum except the extra gold peak. The presence of gold peak is due to the thin coating on the sample surface to make it conducting, which is required to record the FE-SEM.The compositionalstoichiometry of the Nickel ferrites observed by EDAX spectra are in good agreement with the stoichiometriccalculation.

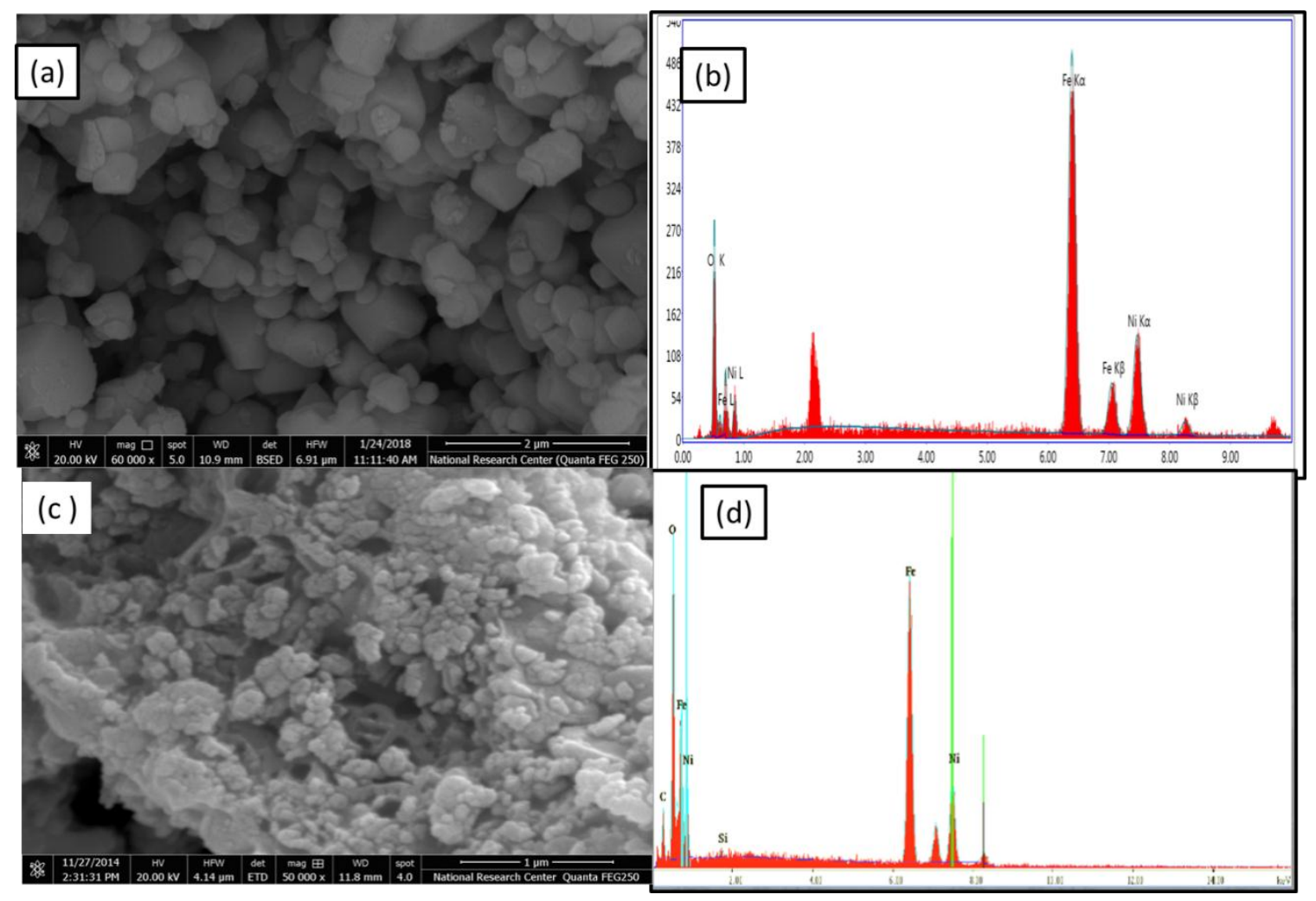

Fig.4 (a) FE-SEM (b) EDAX patterns of $\mathrm{NiFe}_{2} \mathrm{O}_{4}$ (ceramic method), (c) FE-SEM (d) EDAX patterns of $\mathrm{NiFe}_{2} \mathrm{O}_{4}$ (citrate method) 


\subsection{High Resolution Transmission Electron Microscope (HR-TEM) with SAED}

HR-TEM helps to visualize the inherent matrix of individual particles size, morphology and structure of nickel ferrite nanoparticles. Fig.5a, c depicts the HR-TEM images of the $\mathrm{NiFe}_{2} \mathrm{O}_{4}$ synthesized by ceramic and citrate method which confirms the clear morphology of $\mathrm{NiFe}_{2}$ nanoparticles. The image reveals that the synthesized $\mathrm{NiFe}_{2}$ nanoparticles are cubic in shape.

The selected area electron diffraction (SAED) pattern of the cubic shaped $\mathrm{NiFe}_{2} \mathrm{O}_{4}$ nanoparticles is shown in Fig.5b, d.All spots are identified as the diffractions from cubic $\mathrm{NiFe}_{2} \mathrm{O}_{4}$, which reveals the crystalline nature of $\mathrm{NiFe}_{2} \mathrm{O}_{4}$ nanostructure.

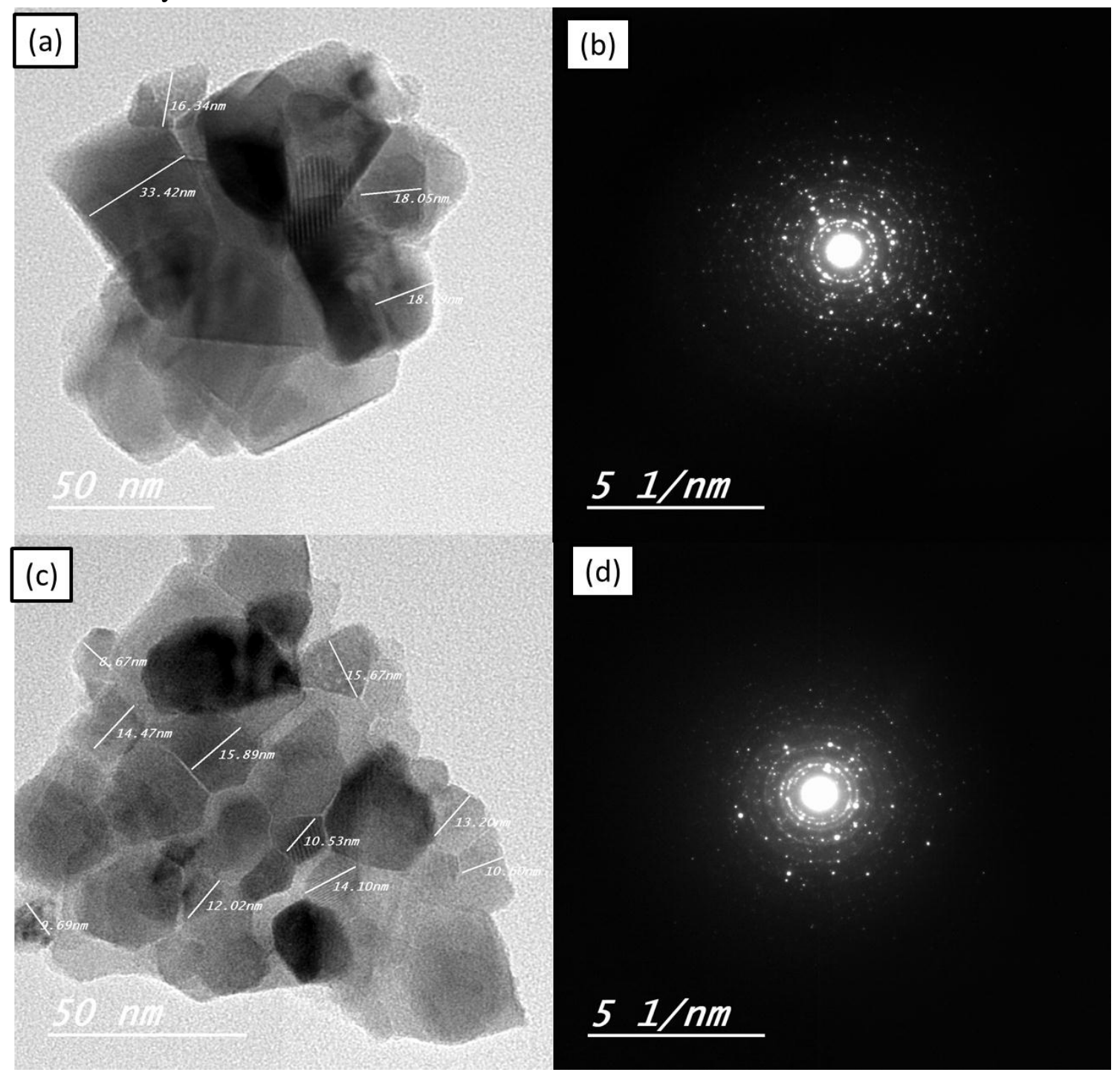

Fig.5 (a) HR-TEM (b) SAED patterns of sample S1, (c) HR-TEM (d) SAED patterns of sample S2 


\subsection{VSM analysis}

Magnetic properties of the synthesized nickel ferrite nanoparticles sample is characterized by VSM (Vibrating sample magnetometer) at room temperature $300^{\circ} \mathrm{K}$. Shape and size of the nanoparticle highly affectsThe magnetic properties of the material [11]. Fig. 6 shows hysteresis loop obtained is "S" shape curve that showsthe sample prepared by the citrate method has superparamagnetic behavior, Table 5depicts the values ofCoercivity (Hc), saturation magnetization(Ms) ,Squareness ratio $\left(\mathrm{M}_{\mathrm{r}} / \mathrm{M}_{\mathrm{s}}\right)$ andRetentivity $\left(\mathrm{M}_{\mathrm{r}}\right)$. Which is significantly high as compared to the saturation magnetization of the bulk nickel ferrite (50.4 emu/g)[12] and reported value for the multi domain bulk nickel ferrite $(55 \mathrm{emu} / \mathrm{g})$. Increased in the value of Hc can be ascribed to the grain growth. The calculated values of squareness ratio of the sample are below 0.5 clearly shows that thenickel ferrite nano-particles synthesized through ceramic and citrate method are multi-domain in nature.

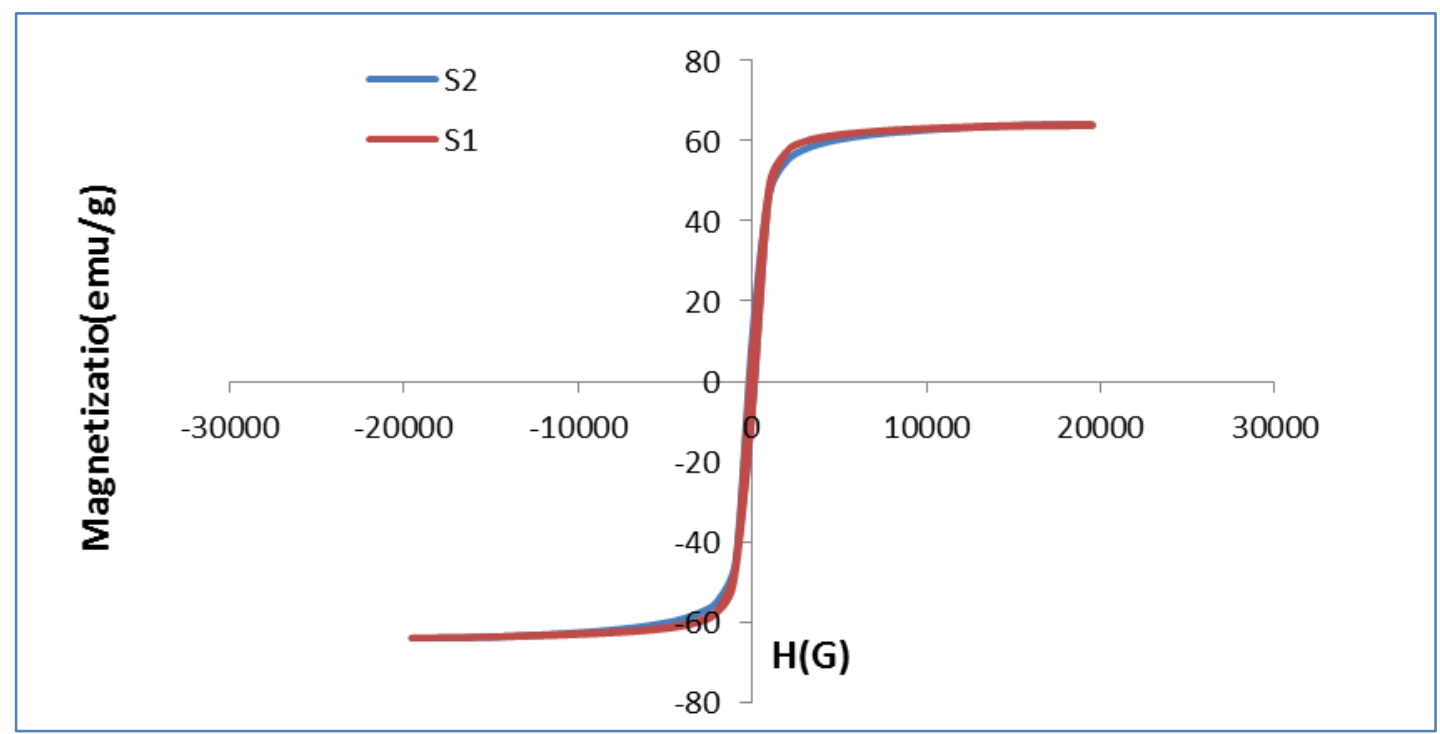

Fig.6 Magnetic hysteresis curve for nickel ferrite nanoparticles measured at room temperature.

Using the value of saturation magnetization at room temperature, the magnetic moment per formula unit in Bohr magneton ' $\mu_{\mathrm{B}}$ 'is calculated by the following equation [13]:

$$
\mathrm{n}_{\mathrm{B}}=\frac{\mathrm{Mwt} \times \mathrm{Ms}}{5585}(1)
$$

The magnetic moment per formula unit in Bohr magneton wasalso calculated according to the Neel's ferrimagnetic theory as,

$$
\mathrm{n}_{\mathrm{B}}=\mathrm{M}_{\mathrm{B}}-\mathrm{M}_{\mathrm{A}}(2)
$$


Where $M_{B}$ and $M_{A}$ are the magnetic moments in Bohr magneton $\left(\mu_{B}\right)$ for $A$ and $B$ sites. The magnetic moments for $\mathrm{Fe}^{3+}$ and $\mathrm{Ni}^{3+}$ ions are 5 and $2 \mu_{\mathrm{B}}$, respectively, which are used in the present calculations. Theresults are summarized in Table 5.

Table 5 Magnetic properties of synthesized sample-S1 (ceramic method) and sample-S2 (citrate method).

\begin{tabular}{c|c|c|c|c|c|c}
\hline Sample & $\begin{array}{c}\mathbf{M}_{\mathbf{r}} \\
(\mathbf{e m u} / \mathbf{g})\end{array}$ & $\begin{array}{c}\mathbf{M}_{\mathbf{s}} \\
(\mathbf{e m u} / \mathbf{g})\end{array}$ & $\mathbf{M}_{\mathbf{r}} / \mathbf{M}_{\mathbf{s}}$ & $\mathbf{H}_{\mathbf{c}}(\mathbf{G})$ & \multicolumn{2}{|c}{$\mathbf{n}_{\mathbf{B}}$} \\
& & & & & & \\
\hline S1 & 7.7215 & 64.122 & 0.12042 & 137.82 & 2 & 2.690 \\
S2 & 10.819 & 64.148 & 0.16866 & 10.819 & 2 & 2.692 \\
\hline
\end{tabular}

\section{Conclusion}

$1-\mathrm{NiFe}_{2} \mathrm{O}_{4}$ ferrites have been successfully synthesized by ceramic and citrate method andsuccessful formation of cubic spinel structure with F d -3 m space group confirmed by X-ray diffraction analysis. Thecrystallite size, the lattice parameterand $\mathrm{X}$-ray density were found using the XRD parameters. There is no difference between the preparation methods in That they all reveal the single phase with cubic structure.

2- The value of lattice parameter is highest in the ceramicmethod while its value decreases in all the wet methodsdepending on the particle size and the melting point of theraw materials. The sample prepared by the citrategivesnanometric crystal size.

3-FE-SEM micrographs and EDAX analysis confirms the chemical compositions, which support our observations on the structure of the ferrite.

4- The Magnetic hysteresisloop of nickel ferrites confirms the formation of superparamagnetic behavior.

\section{References}

ACeylanab et al. J. Magn. Magn. Mater. 320857 (2008)

Carbonin, S, Martignago, F, Menegazzo, G, Negro, A: X-ray single-crystal.

Hai-Ming Fan, Jia-Bao Yi, Yi Yang, Kiang-Wei Kho, Hui-Ru Tan, Ze-Xiang Shen, Jun Ding, Xiao-Wei Sun, O.E. Malinicaroleneolivo,Y.-P. Feng, ACS Nano 3, 2798-2808 (2009).

H. Kavas, A. Baykal, M.S. Topark, Y. Koseoglu, M. Sertkol, B. Aktas, J. Alloys Compd. 479 (2009) 49-55.

KamelliaNejati and RezvanhZabihi, Chemistry Central Journal 2012, 6:23 
K.Maaz, ArifMumtaz, S. K. Hasanain, Abdullah Ceylan, Synthesis and magnetic properties of cobalt ferrite $\left(\mathrm{CoFe}_{2} \mathrm{O}_{4}\right)$ nanoparticles prepared bu wet chemical route, J. of Magne and Magn Mater 308, 2007, 289-295.

KMaaz et al. J. Magn. Magn. Mater. 3211838 (2009).

Lawrence Kumar, Pawan Kumar, Amarendra Narayan and ManoranjanKar, International Nano Letters 2013, 3:8

P.Sivakumar, R.Ramesh ,A.Ramanand ,S.Ponnusamy ,C.Muthamizhchelvan, Materials Research Bulletin 46 (2011) 2204-2207

RavindraSen, Pranat Jain, Ravi Patidar ,Sanjay Srivastava, R. S. Rana, Nitish Gupta, Materials Today: Proceedings 2 ( 2015 ) 3750 - 3757

R.Suresh,P. Moganavally, M.Deepa,Synthesis and Characterization of Nickel ferrites nanoparticles,Int.J. ChemTech Res. 2015, 8(5),pp 113-116.

Suresh Sagadevan, ZairaZamanChowdhur, Rahman F. Rafique, Materials Research. 2018; 21(2): e20160533

Yu.A. Mirgorod, N.A. Borshch, V.M. Fedosyuk, G.Yu. Yurkov, Inorganic Materials, 2013, Vol. 49, No. 1, pp. 109-113. 


\section{الملخص باللغة العريبة}

الخواص التركيبية والمغناطيسية لمتراكبات النيكل فيريت النانومترية المحضرة بطريقة تفاعل الحالة الصلبة و سيترات السائل الجيلاتيني

ريم محمد حمدي 1, مسرات بكر صديق, , يحيي محمد عباس2, محمد علي احمد3 3

1 قسم الفيزياء- كلية البنات - جامعة عين شمس - القاهرة- مصر

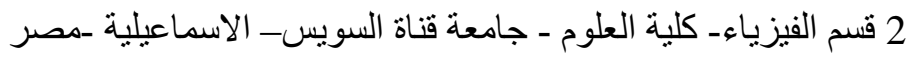

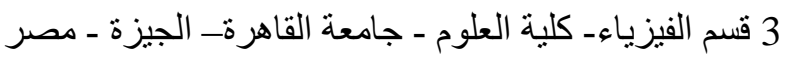

ملخص البحث:

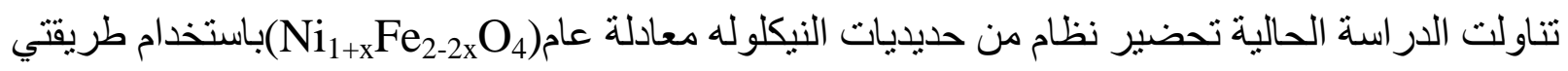

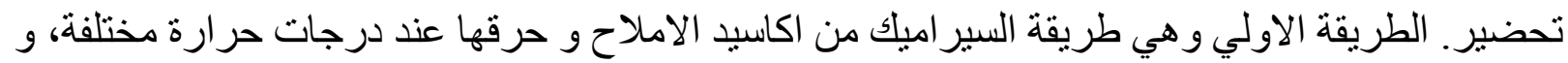
الطريقة الثانية هي طريقة الاحتر اث الذاتي لنترات المعادن بستخدام حمض النيد الستريك.

وقد اجريت علي العينات التي تم تحضير ها القياسات المختلفة باستخدام وسائل معملية مثل حيود الاشعة

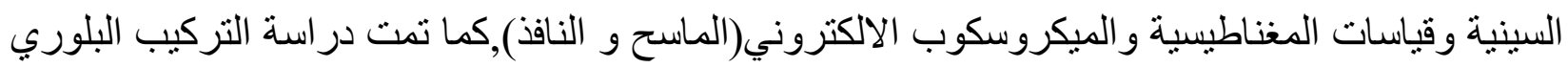
للعينات.

فأظهرت النتائج ان العيناتتبع النظام المنتظم (النظام المكعبي متمركز الوجه)و تبين من تحليل النتائج باستخدام

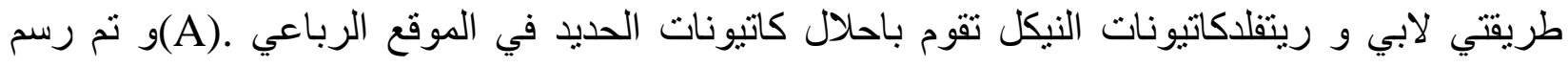

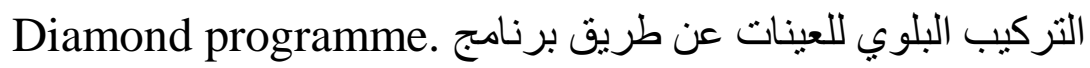

و اظهرت نتائج الميكرسكوب الالكتروني ان العينات تتكون من جسيمات في نطاق النانومتري وتتبع النظام

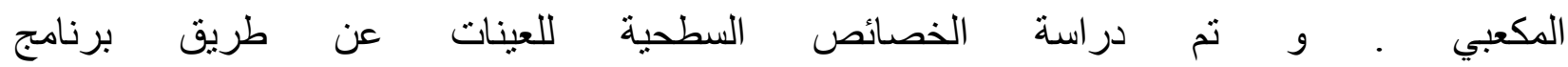

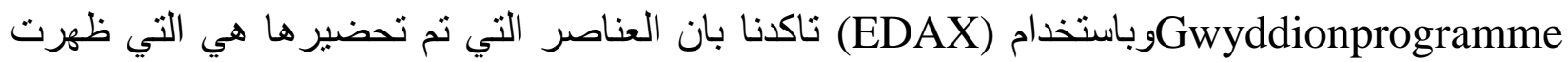

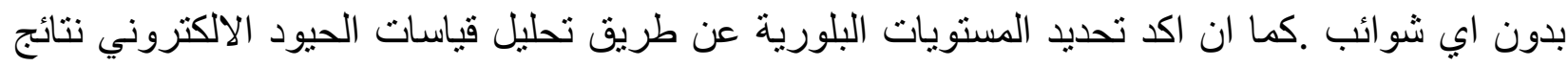

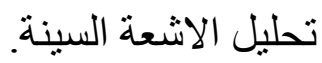

وتم در اسة الخو اص المغناطيسية. وقد لوحظ ان المغنطة العظمي للعزوم لحديديات النيكل النانومتري

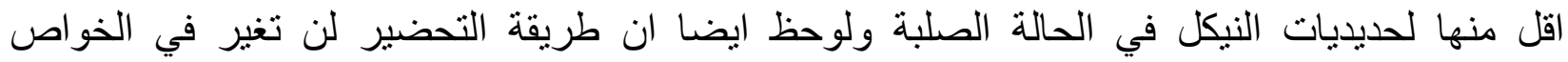

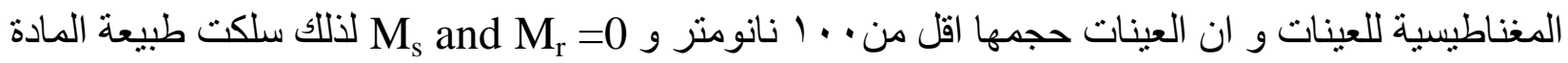
superparamagnetic 